УДК 327

DOI 10.30970/vir.2019.47.0.10266

ORCID ID: 0000-0001-5245-0597

\title{
SOFT POWER IN THE PRIORITIES OF POLISH DIPLOMACY FOR 2019
}

\author{
Malwina Hopej \\ Uniwersytet Wroclawski, Institute of International Studies, \\ ul. Koszarowa 3, Wroctaw, Polska, 51-149, \\ e-mail: malwina.hopej@gmail.com
}

Information of the Minister of Foreign Affairs on Polish Foreign Policy Tasks is an annual speech presenting the main line of action of the Ministry of Foreign Affairs Republic of Poland. The aim of the article is to present the assumptions for 2019 through the prism of soft power. Attractiveness of culture and values offered by the state, being the fundamental attributes of soft power understood as the ability to create other preferences of people, which may influence the way institutions and even the international system function, are important factors forming foreign policy, although in the case of Poland this range is limited only to the region of Central and Eastern Europe. Since Jacek Czaputowicz was appointed Minister of Foreign Affairs, historical policy as well as greater involvement of the Polish community in building a positive image of Poland on the international arena have been included in this catalogue.

The text consists of four main parts. The first one is a theoretical layer, which is an introduction to the soft power of the title. The next is the placement of the Ministry of Foreign Affairs on the political scene and the presentation of the assumptions for 2018. The last one is devoted to soft power categories in the Information on the tasks of Polish foreign policy for 2019. It was divided into four smaller parts, each preceded by a theoretical introduction: norms and values; the importance of the historical factor in the creation of soft power; culture; diplomacy; the role of the Polish community in building the image of the Republic.

Key words: foreign policy; Polish Ministry of Foreign Affairs; soft power; diplomacy; culture; historical policy.

\section{Introduction.}

Information of the Minister of Foreign Affairs on Polish Foreign Policy Tasks is an annual speech presenting the main line of action of the Ministry of Foreign Affairs Republic of Poland for the current year. It outlines a framework that will be determined by permanent points of work of the Ministry of Foreign Affairs, often based on the anniversaries of historical events falling on a given year. Historical policy occupies an important place in the policy of the currently ruling party - Law

(C) Hopej Malwina, 2019 
and Justice (Polish: PiS, Prawo i Sprawiedliwość). Its aim is to bind the society together on the basis of identity, customs, history, which make up the common culture that distinguishes Poland from other countries of Western civilization. It should also be remembered that history, in government policy, is more controversial than culture; Poland is still struggling with the so-called settlement of the previous system - the moral qualification of acts of people acting for the glory of the People's Republic of Poland (Polish: PRL), fighting against the sovereignty and independence of the Republic of Poland (RP). Culture is a more neutral subject, associated with the carrier of identity, positive national features, in the past national identity (the times of partitions, reduced to 123 years of absence of Poland from the political map of the world). Values, on the other hand, being another area of the eponymous soft power, are a combination of the best creations of history and culture, and through the possibility of creating and promoting a positive image of the state in international relations, they are important points in conducting foreign policy.

The article presents the priorities of Polish diplomacy for 2019 through the prism of soft power. The attractiveness of culture and values offered by the state, being the basic attributes of soft power understood as the ability to create other preferences of people, which may influence the way institutions even the international system function, are important factors shaping foreign policy, although in the case of Poland this range is limited only to the region of Central and Eastern Europe. The text consists of four main parts. The first is the theoretical section, which is an introduction to the eponymous soft power. The next one is the presentation of the Ministry of Foreign Affairs and the assumptions of foreign policy for 2018. The last one is devoted to soft power categories in the Information on the tasks of Polish foreign policy for 2019. It was divided into four smaller parts, each preceded by a theoretical introduction: norms and values; the importance of the historical factor in the creation of soft power; culture; diplomacy and the role of the Polish Community Abroad in building the image of the Republic of Poland.

\section{What is soft power?}

«Modern world requires effective explain of our reasons, clarify our position and decisions, and building a positive image of our country. We need to properly identify and react to emerging threats» ${ }^{1}[1]$ - these words of Minister Czaputowicz contained in his presentation of information may serve as an example of practical use of soft power. Joseph Nye defines soft power as «the ability to establish preferences that tend to associate with intangible assets such as an attractive personality, culture, political values, institutions as well as policy which is seen as legally-valid or having moral authority» [2]. For Kenneth Boulding, it is one of the types of authority that is understood as a power to identify with the influencing subject by unifying a group of recipients [3]. Jeremy Ryfkin emphasises that the main task of soft power is to attract people to one's side (co-opting), not coercing [4], and according to Steven Lukes, soft power should be viewed in terms of effectiveness, i.e. the change of motivation of the entities to which the force is directed [5]. According to Nye, the country, on the international arena, can achieve the assumed results, because other countries, by

1 Own translation. 
imitating and seeking to achieve a similar standard of living, want to choose, imitate the same path and policy [6]. What is important, soft power can replace traditional forms of force, which include military means or economic sanctions. Such a thesis is right, especially nowadays, when peaceful methods of gaining support and trust are preferred [7] also the price of military operations, understood as financial and image costs, has increased significantly.

It is worth noting that the mere possession of soft power resources is not synonymous with effectiveness, which is determined primarily by the subject of decision-making ability (the sender of the message), the context and, above all, the recipient of the message - it is in relation to their expectations and skills that the message (agenda), tools and resources should be adjusted, which increases the likelihood of attraction (co-opting). As Anna Wojciuk emphasizes, the content as well as effectiveness of this power depend on values considered important and valuable by the recipients at a given moment, because «soft power sources do not exist regardless of social reality. They are intersubjectively constructed and change over time» [8].

In the article, soft power, after Robert Loś, refers to «elements of culture, values, education, efficiency of state institutions or diplomacy. It also includes certain aspects of economics, such as innovation or participation in the creation and functioning of complex social, economic, political structures and norms» [9].

\section{The Minister and the Ministry of Foreign Affairs of the Republic of} Poland.

The Minister of Foreign Affairs is the supreme public administration body, which is provided by the Ministry, which is a budgetary unit. The current name of the Ministry was established in $3^{\text {rd }}$ Nov. 1999 by virtue of the regulation of the Council of Ministers [10] and functions on the basis of regulations, ordinances and announcements of the Prime Minister [11]. Currently, it is one of the 17 ministries comprising the Council of Ministers, subordinated to the President (Prime Minister of the Republic of Poland).

According to the current Act of $4^{\text {th }}$ Sept. 1997 on departments of government administration, the activities of the Ministry of Foreign Affairs in the field of culture are reduced to: supporting cultural and educational institutions abroad; responsibility for issues related to public and cultural diplomacy, as well as supporting activities promoting Polish economy, culture, language, tourism, technology and science. In the case of foreign policy and diplomacy in terms of soft power, the Ministry is responsible for creating the international image of the Republic of Poland; cooperation with the Poles living abroad [12]. Currently, the Department of Public and Cultural Diplomacy is responsible for coordinating activities related to culture, and for contacts with the Polish community - the Department for Cooperation with Polish Diaspora and Poles Abroad, which are subordinate to the Secretary of State for Polish Community Abroad, European Policy and Public Diplomacy [13].

On $9^{\text {th }}$ Jan. 2018, Prof. Jacek Czaputowicz, theoretician and practitioner of international relations, was appointed to the position of Minister. He is a long-term employee of the Ministry (he was the director of the Department of Strategy and 
Foreign Policy Planning at the Ministry of Foreign Affairs), Doctor of Science (DSc) in Human Sciences and the author of over 100 articles and academic monographs [14].

4. Tasks of the Polish foreign policy for 2018.

Czaputowicz, in his first presentation of the foreign policy tasks for 2018, which he delivered only two months after assuming the position of Minister, emphasized that «international position of Poland results from its strong position in Europe» [15]. He then presented four theses concerning: Poland's position in the world, the European Union (EU), security and relations with the United States, as well as policy towards Russia [16]. The vision of the EU boils down to the existence of three spheres in the crisis - institutional, axiological, external security - resulting in the growing euroscepticism and renationalisation policies of states of Europe, and consequently, the weakening of this organisation on the international arena. The role of the USA is limited to military presence on the continent and the North Atlantic Treaty Organization (NATO), an alliance of fundamental importance for the military security of Poland also the region of Central and Eastern Europe. The last thesis referred to policy of Russia aimed at revising the political order shaped after 1989, which could threaten the building of subjectivity and sovereignty of Poland [17].

Unfortunately, in the presentation of the assumptions of foreign policy for 2018, hence the year in which Poland regained its independence [18], cultural issues were marginalised. Culture appeared only in reference to Lithuania and the numerous Polish minority, in the context of the extension of the transmission of five of Polish Television (TVP) channels to the Vilnius region, serving to maintain the ties between the compatriots and their homeland. The second reference was in the point signalling the activities promoting Polish culture and political traditions, «with particular emphasis on the civilizational achievements of the Republic of Poland as one of the oldest parliamentary democracies in Europe» - in 2018 also coincided with the 550 anniversary of parliamentarianism.

Among the tasks of diplomacy, the Minister paid special attention to informing, or rather reminding, world public opinion about the behaviours of the Poles during World War II: fighting the occupant, agitating for the creation of an independent country, and above all alarming the allies about the fate of Jews exterminated by the Third Reich, Poles and other ethnic also national groups who are Polish citizens. He also referred to the priorities in the field of security - diplomacy is to act to increase the efficiency of NATO activities understood as a support force, accelerate decisionmaking processes or increase the mobility of individuals. Czaputowicz also drew attention to economic diplomacy - promoting technological cooperation between Polish companies and foreign scientific and research institutions, or promoting Poland as a country friendly to foreign investors, innovation and intellectual capital.

The organisation of COP242, the largest of the world climate conference with 20,000 delegates from all over the world (Katowice, $2-14^{\text {th }}$ Dec. 2018) [19], can be treated as an «opportunity to promote Silesia all Poland as an open and modern country that cherishes its historical and natural heritage». Other values recorded in the

\footnotetext{
${ }^{2}$ COP2 4 is the informal name for the $24^{\text {th }}$ Conference of the Parties to the United Nations Framework Convention on Climate Change (UNFCCC).
} 
speech concern the sphere of international relations and are presented through the prism of non-permanent membership of the UN Security Council, giving «more influence and responsibility for global problems». According to Czaputowicz, Polish actions are focused on strengthening the principles of international law, preventing conflicts and combating new threats to peace and security. The country stands for «full respect for the fundamental principles of international law: inviolability of borders, respect for sovereignty, respect for human rights and renunciation of military force», as exemplified by the chairmanship of the Preparatory Committee for the Nuclear Non-Proliferation Treaty Review Conference to be held in 2020. Great importance is also attached to humanitarian issues, including the protection of the rights of religious communities.

The national and regional values highlighted by the Minister for Foreign Affairs are presented for reasons of state. «The obvious reason for the state of Poland is to guarantee national independence and also sovereign statehood. It is also to ensure the civilizational development of Poland in subjective relations within the international community. Moreover, European solidarity is a part of transatlantic solidarity, and therefore solidarity of the whole West», which can be read as the necessity of active action on the forum of the European Union and NATO, which are the two most important, politically and militarily, organizations united by Europe.

In 2018, the year of the centenary of regaining independence, a number of activities promoting Polish culture and political traditions were planned, with particular emphasis on the civilizational achievements of the Republic of Poland, which is one of the oldest parliamentary democracies. The speech, which was showed by Minister did not contain details, but on the occasion of these celebrations, Poland wanted to «show its solidarity and awareness of the community of historical fate with other nations in our region, which a hundred years ago, together with us, became independent». Conterminously in the Information given in 2019, the Polish Community Abroad was defined «as an important element of the national community», a group of about 20 million compatriots and people with Polish roots. It can actively promote the interests of the Republic of Poland, its culture, and the right of state - «through close cooperation with Polish diplomatic and consular missions», assuming the development of Polish Diaspora Consultative Council, organizations as well as Polish education.

Information on the tasks of the Ministry of Foreign Affairs for 2019, in contrast to Information for 2018, associates culture with historical issues and the wider presence of Poland on the international arena, especially in relation to public diplomacy.

5. Information of the Minister of Foreign Affairs on the tasks of the Polish foreign policy for 2019.

Information of the Minister of Foreign Affairs on Polish Foreign Policy Tasks was presented by Jacek Czaputowicz on $14^{\text {th }} 2019$ before the assemblies in the Parliament of the Republic of Poland: President of the Council of Ministers (Prime Minister of Poland), Council of Ministers, Members of Parliament, Members of the Diplomatic Corps. Traditionally, the speech is followed by a debate with the participation of members of the Polish Parliament. 
The speech can be divided into four main parts referring to the assumptions of soft power. They concern the anniversaries of historical affairs, affecting the shape of values presented in international relations (ideological-diplomatic and historical layers) and the activities of diplomacy, culture, as well as economy and the Polish community, whose role is to present positive images of Poland and values on the international arena.

\subsection{Standards and values.}

In accordance with the idealistic spin in international relations, norms and ethics are important variables in the behaviour of countries. The former, in the understanding of soft power, embed the activities of states in international public law, which strengthens not only the international community, but also justifies and makes credible the activities undertaken by the state. It also makes it possible to gain allies of national rationale [20]. Soft power is associated with a specific contextualization, so in order to act, it needs to define a minimum of common norms [21], and such a basis may be a palette of arrangements of international law (e.g. declarations, conventions, etc.) or customaries international law that have been constructed over the years.

More difficult is the case with values, because not all civilisations share the same values and understand them in the same way, the best example of which is the approach to the broadly understood rights of women. Moreover, unlike norms or supranational level, they very often concern internal policies. There is no possibility of imposing foreign and incomprehensible values from above, the best example of which is the forceful attempt to introduce democracy in the Middle East, seen as an attempt to impose Western hegemony. Explanation (the role of education and contextualisation) and the possible introduction of new norms, preceded by the acceptance of the recipient, are postulated to be better for both sides by soft power. It seems that values, understood as an expression of a close perception of the world by international relations actors, may develop on the basis of civilizational similarity, while universal norms, encountered in most cultural circles, have a greater probability of being adopted [22].

In the Information presented by Minister Czaputowicz, the values offered by Poland to the global community were presented through the prism of historical affairs. «The anniversaries provide an excellent opportunity to present the role of Poland and its contribution to groundbreaking events in the world». This year marks, among others, the $30^{\text {th }}$ anniversary of the victory of Independent Self-governing Labour Union «Solidarity» (NSZZ, Polish: NSZZ «Solidarność») in the elections of $4^{\text {th }}$ June 1989 and the $75^{\text {th }}$ anniversary of the outbreak of the Warsaw Uprising (from the $1^{\text {st }}$ Aug. 1944 to the $2^{\text {nd }}$ Oct. 1944), in which the Poles, despite zero chances of success, fought against the German occupier for dignity.

The most important place in the quoted speech is occupied by the ideals of this trade union - in 2019 it is the $30^{\text {th }}$ anniversary of the defeat of the communist system, which gave Central and Eastern Europe the chance for the freedom it wanted. Solidarity, the title value of the NSZZ movement, is an extremely universal and still valid value. It is connected with the lack of self-determination of nations and external 
Malwina Hopej

interference of stronger states (e.g. the Kremlin), as well as with the idea of common, nationwide integration in order to regain not only sovereignty but also a dignified life.

2019 is also the $15^{\text {th }}$ anniversary of accession of Poland to the European Union, which was celebrated on 1 May - in Warsaw a meeting of the leaders of the countries that joined the EU after 2004 was organised Together for Europe - High Level Summit [23]. It not only strengthened the image of the Republic of Poland as a leader of Central Europe, but also made it possible to create a common opinion on the directions of community development. Perhaps it will be consistent with the vision presented in Information of the Ministry of Foreign Affairs, in which the Union is to be strong thanks to the broad support of the citizens of the countries comprising the organization, supporting economic growth, prosperity, development of the potential of societies and the common market, as well as observance of four freedoms: movement of goods, capital, people, services, reducing differences in the quality of life.

The assumptions of the «Solidarity» movement and the ideals of universal prosperity while maintaining political distinctiveness are extremely important for Poles. It happens that these values are not understood by the decision-makers of the European Union (it is caused by different historical experiences), despite the fact that they are universal and have vital role in foreign policy. An example of the implementation of these values are activities on the ground of diplomacy and economic promotion. Polish presence in the economic sector is presented primarily through the prism of involvement in the implementation of the «Agenda for Sustainable Development - 2030», as well as support for developing regions: in 2018, over PLN 2.8 billion was allocated for Official Development Assistance (ODA), the aim of which is to combat poverty or to support people affected by armed conflicts. The Republic of Poland also supports the dissemination of the democratic system in the world, while these activities boil down to the practical application of the assumptions of soft power. An example of this activity is the annual organisation of the Warsaw Dialogue for Democracy [24], in which several dozen representatives of civil society participate, or «Pro Dignitate Humana» [25], the award of the Minister of Foreign Affairs, which was given to Ołeh Sencow last year.

\subsection{The role of history in the creation of soft power.}

In the case of Polish foreign policy, one can speak of a kind of triad consisting of mutually reinforcing elements: history-value-diplomacy. The history of Poland, especially the most recent one, after 1980, influences the values that may constitute universal export products, such as solidarity, unity, equality, self-determination of the nation, and a shift towards Euro-Atlantic freedom. The Ministry of Foreign Affairs is to be responsible for their promotion. In spite of this, Information does not devote as much attention to it as to culture. History is presented through the prism of diplomacy and the need to disseminate knowledge, because not infrequently a misunderstanding of the historical context affects current politics and may even lead to diplomatic disputes. The most glaring examples are thought abbreviations perceived in Poland as intentional misrepresentations, especially when they appear in the German media: «Polish death camps» or «Polish extermination camps» [26] concerning Nazi (German) camps located on the present-day Polish territory (Poland, during World 
War II, was under German occupation and could not oppose the criminal policy of the Third Reich).

To this end, the Ministry of Foreign Affairs, in cooperation with representatives of the Polish community, the Adam Mickiewicz Institute or the Institute of National Remembrance - Commission for the Prosecution of Crimes against the Polish Nation, have taken a number of measures to disseminate knowledge about the history and heroic attitudes of Poles, including the production and promotion of a film about the members of the so-called Berne Group (a group of Polish diplomats who during the Holocaust issued about 5000 false passports to Jews, thanks to which about 1500 people could survive) [27], or the «Armoured Wings» exhibition in Brussels commemorating the soldiers of General Maczek - the liberators of Flanders [28]. These are only two examples of actions promoting not only Polish history, but also key values for the Ministry of Foreign Affairs: solidarity with other nations, willingness to help states in regaining independence.

\subsection{Culture.}

Culture is an extremely multidimensional and multifaceted concept which, when properly used - that is, adapted to the internal recipient or, in the case of the universal aspect, to the recipient outside the civilization sphere - may constitute an important resource for international influence. It can also strengthen the potential and build the desirable image of the state, as exemplified by soft power states (great power, local power based on the soft power sector): the United States of America, France, or Great Britain.

Culture can be understood in three ways: as high culture associated with the observance of standards typical for a given civilization (savoir vivre); popular culture - reduced to published books, film productions, television programmes, television games and others. Nowadays, this approach offers the best methods of promoting the state, because it reaches the widest audience, but on the other hand, the government does not always have the possibility to control the messages (especially when they are produced by independent, private producers); the lifestyle - a holistic approach. It includes a collective way of thinking, understanding values and perceiving the outside world, called the linguistic image of the world [29].

In contrast to the dimensions of culture, Robert Łoś includes: objects and places of cultural and natural heritage: museums, works of art, archaeological sites and places of historical and cultural value; performing arts (music, festivals, stage arts, fairs); crafts understood as fine arts, photographs, handicrafts; published books and also press; audio-visual and interactive media (film or television productions, radio, Internet, games); creative services, i.e. fashion, interior and landscape architecture, advertising [30].

Countries have a different cultural offer, it is also a result of changes in the course of history, and if used properly, it can enhance the created image. Poland, in contrast to the above-mentioned states-power, cannot boast such a large range of influence. It is often limited to the region of Central and Eastern Europe, which can be described in 
terms of proximity of not only historical experience 3 but also world-view and cultural experiences, thanks to which the generated message can be more effective. However, referring to the dimensions of culture and its three understandings, Poland boasts such famous composers as Fryderyk Chopin and Stanisław Moniuszko; jazzmen Krzysztof Komeda and Tomasz Stańko; poets and writers: Wisława Szymborska, Ryszard Kapuściński, Stanisław Lem; artists: Tamara Łempicka, Magdalena Abakanowicz, Alina Szapocznikow; creations addressed to mass audiences, such as the computer game «The Witcher»; films of the most famous directors - Andrzej Wajda, Agnieszka Holland, Roman Polański, Paweł Pawlikowski; A number of monuments, including the archaeological site of Biskupin Castle, Teutonic Castle in Malbork and other places included in the UNESCO world heritage list; festivals (International Film Festival of the Art of Cinematography Camerimage, Polish Feature Film Festival, Jazz on the Oder River).

Polish Institutes operating in 25 countries of the world, including the United States of America, Japan, India, Russia, play a special role in promoting Poland and its culture (the so-called cultural diplomacy [32]). They are established in order to implement public diplomacy: to ensure presence in international undertakings, maintain contacts with foreign partners in the fields of culture, education, science, social life, but above all to promote the image of Poland as a modern state, successful in peaceful political and economic transformations [33].

Czaputowicz emphasizes, referring to the importance of public diplomacy [34], that «the position of a country depends to a large extent on the opinions formulated on its subject by the world public opinion», which consists primarily of states, their citizens and the largest press agencies. Therefore, the task of the Ministry of Foreign Affairs is to create and promote «a good association with Poland; knowledge and respect for its culture and history are crucial for the success of our undertakings on the international arena».

5.4. Diplomacy. The role of the Polish CommunityAbroad in the creation of the image of the Republic of Poland.

Apart from economic, military, psychosocial and normative means, diplomatic (political) means are included in the means and methods of the foreign policy of the state, determining the style of conducting this policy. They include the official contacts of the state with the external sphere, reduced to forms of diplomatic relations,

3 It is worth mentioning first of all the union of the Crown of the Kingdom of Poland and the Grand Duchy of Lithuania, which united both countries (in the Commonwealth of Two Nations), thanks to which Poland, for centuries, was one of the largest countries in Europe. In the 17th century, the territory of the Republic of Poland included the present-day parts of the territories of Poland, Lithuania, Latvia, Estonia, Ukraine, Belarus and Russia. The next events creating the mentality of Europeans from the Middle East region were partitions (separation of territory by a hostile country). The third partition led in 1795 to the total liquidation of the Republic of the Two Nations, condemning the above nations to existence under the rule of Austria, Russia and Prussia until 1919. These countries regained full sovereignty only at the beginning of the 1990s. (the collapse of the USSR). Shortly after independence was regained, efforts were made to join NATO and the EU. 
while the elementary methods include: consultations (intergovernmental) and exchange of opinions, as well as typical for negotiations: persuasion, compromise, promise of benefits in return for obtaining support, deception, mystification (e.g. using data unknown to the other side) [35].

The quoted Information states that the task of diplomacy is to develop the international architecture that is the most beneficial for Polish security, and thus almost classically: soft power is to strengthen and support hard power. On the other hand, the main field of diplomacy activity is the area of Central and Eastern Europe: «a community of historical experiences, cultural proximity, similar paths of social plus economic development or similar priorities in the EU - these are factors that bring the countries of our region closer together», facilitate the perception of the soft power resources possessed by the Republic of Poland, and thus - create the image of Warsaw as a regional leader, perhaps with a chance to achieve the status of a local power. The other regions were also included in the quoted speech, but they received much less attention than Europe. They were presented primarily through the prism of Polish economic activity (PAIH, ODA) and the Polish Community Abroad.

The Polish Community Abroad is an important part of the creation of the image of Poland and efforts on the international arena included in current Information - thanks to its size and presence in virtually every region of the world, «to actively promote Polish interests. It its especially important to support the Polish Community Abroad to further strengthen security of Poland, raise the profile of reforms implemented by the government and promote the truth about Polish history. We would like our compatriots to become an important ally of the government in promoting Polish national interest, Polish culture, national remembrance and Polish historical narrative». According to Czaputowicz, it was thanks to the compatriots living abroad and their support that the Katyń Massacre Memorial in New Jersey was defended as well as Colonel Franciszek Kornicki [36] won the plebiscite for the symbol of the RAF pilot from World War II.

In order to support the Polish Community Abroad, further development of the Polish Diaspora Consultative Councils operating at foreign institutions, organizations of the Polish Community Abroad, as well as Polish media and education, called by the Minister the guardians of culture and national tradition, was declared. This is particularly important for the Polish Community Abroad from the East and Germany. The Ministry of Foreign Affairs is constantly trying to improve the possibilities of deepening cultural or linguistic identity, and issues related to the rights of Polish Community Abroad and the Poles are still among the issues differentiating Warsaw and Berlin. Likewise a significant problem is the definition of a national minority different from the Polish one, which makes it difficult to teach native languages in schools. Approaches to minorities are also divided between the Poles and the Lithuanians, the latter also do not facilitate the development of Polish education and the admission of the Polish spelling of surnames in documents. However, as the Minister pointed out in his tasks of foreign policy, since 2018 five of Polish Television (TVP) channels have been broadcast in the Vilnius region, «which contributes to the strengthening of Polish identity and immunizes our compatriots against Russian 
disinformation». The effect of trilateral cooperation between the Ministry of Foreign Affairs, Polish Television and the local community of Polish journalists is to create the TVP Vilnius channel, whose task will be to provide the Polish community with information about contemporary Poland, its culture and history [37].

\section{Conclusion.}

Information of the Minister for Foreign Affairs is considered to be a presentation of the priorities and framework for diplomacy activities envisaged for the year in question. In the 2019 speech, soft power took an important place, reduced to four issues for analysis of this document: norms and values; historical factor; culture; diplomacy; the role of the Polish community in building the positive image of the Republic of Poland. The values offered to the international community by Poland were presented through the prism of anniversaries of historical affairs, among which one should mention the high ideals of Independent Self-governing Labour Union - the most fully reflecting the most important values for Poles: solidarity, equality, political independence, self-determination of the nation, the turn towards Euro-Atlantic freedom, as well as the European Union, which, like Poland, aims to support economic growth, prosperity, development of the potential of societies, reducing differences in the quality of life. Furthermore, the activities of the Polish government, which are contained in the above values and norms, are directed exclusively to countries that are culturally close to each other, which makes them more effective. Knowledge of culture and history is crucial for the success of projects undertaken in the international arena. Polish Institutes play a special role in cultural diplomacy, promoting creative activities of Polish artists and intangible cultural heritage. Besides, the quoted Information indicates that the task of diplomacy is to develop the international architecture the most beneficial for Polish security, and the main field of activity, due to cultural proximity, historical experience, a similar level of social and economic development, is the area of Central and Eastern Europe. This task is realized thanks to the Polish Community Abroad, government activity in the economic sphere (PAIH, ODA) and on the Euro-Atlantic ground.

\section{BIBLIOGRAPHY}

1. Informacja Ministra Spraw Zagranicznych o zadaniach polskiej polityki zagranicznej w 2019 r. Por. szerzej: Minister Jacek Czaputowicz o priorytetach polskiej dyplomacji w 2019 roku, https://www.gov.pl/web/dyplomacja/minister-jacek-czaputowicz-o-priorytetach-polskiej-dyplomacji-w2019-roku [30.06.2019].

2. J. S. Nye, Soft power. Jak osiagnqć sukces w polityce światowej, Warszawa 2007, s. 35.

3. K. Boulding, Three Faces of Power, Londyn 1989, s. 15.

4. J. Rifkin, Europejskie marzenie. Jak europejska wizja przyszłości zaćmiewa «american dream», Warszawa 2005, s. 364

5. Por. szerzej: R. Łoś, Soft power we wspyłczesnych stosunkach międzynarodowych, Łydź 2017, s. 60.

6. J. S. Nye, op. cit., s. 34.

7. M. Ryniejska-Kiełdanowicz, Public relations Polski $w$ okresie kandydowania do Unii Europejskiej, Wrocław 2007, s. 59. 
8. A. Wojciuk, Od zagrożenia normatywnego do soft power: teoretyczne aspekty analizy dyfuzji modeli instytucjonalnych [w] «Stosunki Międzynarodowe - International Relations» nr 3 (t. 53) 2017, s. 60 .

9. R. Łoś, op. cit., s. 63.

10. Rozporządzenie Rady Ministryw z dnia 3 listopada 1999 r. w sprawie utworzenia Ministerstwa Spraw Zagranicznych, https://www.msz.gov.pl/resource/192f44e4-7104-455b-8d49-9d543b323361:JCR [20.06.2019].

11. Status Prawny, https://msz.gov.pl/pl/ministerstwo/ministerstwo_organizacja/status_prawny/ [dostęp 20.06.2019 r.].

12.Zadania i kompetencje Ministra Spraw Zagranicznych, https://www.msz.gov.pl/pl/p/msz_pl/ ministerstwo/minister/zadania_i_kompetencje/zadania_i_kompetencje_ministra_spraw_zagranicznych [21.06.2019].

13. Struktura organizacyjna, https://msz.gov.pl/pl/ministerstwo/ministerstwo_organizacja/ struktura_organizacyjna_msz/ [20.06.2019].

14. Jacek Czaputowicz, https://www.premier.gov.pl/ludzie/jacek-czaputowicz.html [20.06.2019].

15. Por. szerzej: Informacja Ministra Spraw Zagranicznych o zadaniach polskiej polityki zagranicznej w $2018 \mathrm{roku}$, https://www.msz.gov.pl/pl/ministerstwo/minister/wystapienia/informacja ministra_spraw_zagranicznych_o_zadaniach_polskiej_polityki_zagranicznej_w_2018_roku;jsessionid=7 170C397C5D001EB00C30BC5C36BA006.cmsap1p [15.06.2019].

16. Polska polityka zagraniczna w 2019 r. Exposŭ szefa MSZ Jacka Czaputowicza w Sejmie, http://www.tvpparlament.pl/aktualnosci/polska-polityka-zagraniczna-w-2019-r-expos-szefa-msz-jackaczaputowicza-w-sejmie/41698233 [20.06.2019].

17. Jakie zatożenia polskiej polityki zagranicznej? Expose w Sejmie, http://radioszczecin.pl/ 6,368708,jakie-zalozenia-polskiej-polityki-zagranicznej-e [20.06.2019].

18. Por. szerzej: Независимой, https://niepodlegla.gov.pl/ru/, Independence, https://niepodlegla. gov.pl/en [04.07.2019].

19. Overview Schedule 2-14 December 2018, https://cop24.gov.pl/fileadmin/user_upload/ files/COP24_brochure.pdf [14.07.2019].

20. R. Łoś, op. cit., s. 76.

21. A. Wojciuk, op.cit. s. 61.

22. Por. szerzej: R. Łoś, op. cit., s. 76-80.

23. Premier Mateusz Morawiecki podczas «Together for Europe - High Level Summit», https://www.premier.gov.pl/wydarzenia/aktualnosci/premier-mateusz-morawiecki-podczas-together-foreurope-high-level-summit.html [04.07.2019].

24. Warsaw Dialogue for Democracy, https://www.msz.gov.pl/pl/p/wdd_pl/warszawski_dialog_ na_rzecz_demokracji [04.07.2019].

25.Minister Jacek Czaputowicz udaje się z wizyta na Ukrainę, https://www.msz.gov.pl/pl/ aktualnosci/wiadomosci/minister_jacek_czaputowicz_udaje_sie_z_wizyta_na_ukraine [ 04.07.2019].

26. Obama angers Poles with 'death camp' remark, https://www.bbc.com/news/world-europe18264036 [04.07.2019]. Odpowiedzią na te powtarzające się kłamstwa są kampanie informacyjne Truth about camps, ktyrej przykładem jest strona opracowana przez Instytut Pamięci Narodowej: German Camps on Occupied Polish Territories during 1939-1945 https://en.truthaboutcamps.eu/ [04.07.2019], a także German Death Camps not Polish https://www.germandeathcampsnotpolish.com/ [04.07.2019].

27. Pokaz filmu «Paszporty Paragwaju» - Warszawa, 30 stycznia 2019, https://ipn.gov.pl/pl/ aktualnosci/64843,Pokaz-filmu-Paszporty-Paragwaju-Warszawa-30-stycznia-2019.html [04.07.2019].

28. Otwarcie polsko-belgijskiej wystawy «Pancerne Skrzydla»-Bruksela, 28 stycznia 2019, https://ipn.gov.pl/pl/aktualnosci/65317,Otwarcie-polsko-belgijskiej-wystawy-Pancerne-SkrzydlaquotBruksela-28-stycznia-2.html [04.07.2019].

29. Por. Szerzej: M. Hopej, The essence of true HOMELAND. The ways of understanding the value of the HOMELAND by young Poles from Poland and Ukraine having Polish citizenship or formal adherence to the Polish nation [w] «Review of Nationalities» 2017, t. 7, s. 279-304.

30. R. Łoś, op. cit., s. 80-85.

31. Por. W. Oleksiak, Learn the History of Poland in 10 Minutes, https://culture.pl/en/article/learnthe-history-of-poland-in-10-minutes [04.07.2019]. 
Malwina Hopej

ISSN 2078-4333. Вісник Львівського університету. Серія міжнародні відносини. 2019. Випуск 47

32. M. Ratajczak, J. Ziobroń, Model dyplomacji publicznej państw matych. Przypadek Szwajcarii i Litwy [w] «Sprawy Międzynarodowe», rok LXVI nr 4/2013, s. 71-72, 75.

33. Instytuty Polskie, https://www.msz.gov.pl/pl/p/msz_pl/polityka_zagraniczna/dyplomacja_ publiczna/instytuty_polskie/instytuty_polskie/_rp0x2Content!143030@16575_pageNo/1 [30.04.2019]

34. B. Ociepka, Nowa dyplomacja publiczna - perspektywa teorii stosunkyw międzynarodowych $i$ komunikowania politycznego [w] «Przegląd Strategiczny» 2012, nr 1, s. 129-139.

35. R. Łoś, op. cit., s. 94-97.

36. T. Timoshina, The People's Spitfire Pilot, https://www.rafmuseum.org.uk/blog/polish-thepeoples-spitfire-pilot/ [10.07.2019].

37. Por. szerzej: M. Ratajczak, Ryżnorodność kulturowa w mediach. Doświadczenia europejskie, Wrocław 2012, s. 59-64.

Стаття надійшла до редколегії 30.08.2019

Прийнята до друку 10.09.2019

\section{М'ЯКА СИЛА В ПРІОРИТЕТАХ ПОЛЬСЬКОЇ ДИПЛОМАТІЇ 2019 РОКУ}

\section{Мальвіна Хопей}

Вроцлавськии Університет, Інститут Міжнародних Відносин, вул. Кошарова, 3, м. Врочлав, Республіка Польща, 51-149,

e-mail: malwina.hopej@gmail.com

Інформація Міністра закордонних справ про зовнішньополітичні завдання - це щорічна презентація, в якій представлено основний напрямок діяльності Міністерства закордонних справ Польщі. Метою статті $є$ представлення планів на 2019 рік через призму м'якої сили. Привабливість культури та цінностей, що надаються державою, які є основними атрибутами м'якої сили, розуміються як здатність створювати чужі уподобання, які можуть вплинути на те, як функціонує організація, і навіть міжнародна система, є важливими факторами, що формують зовнішню політику, хоча у випадку Польщі цей діапазон діє тільки в регіоні Центральної та Східної Європи. До цього каталогу, з моменту призначення Яцека Чапутовича на посаду Міністра закордонних справ, була включена історична політика та більша участь польскої діаспори у побудові позитивного іміджу Польщі на міжнародній арені.

Текст складається $з$ чотирьох основних частин. Перша, це теоретичний шар, який $є$ вступом до самої істоти м'якої сили. Наступні дві частини стосуються розташування Міністерства закордонних справ на політичній арені та презентація планів на 2018 рік. Остання частина присвячена категоріям м'якої влади в Інформації Міністра закордонних справ про завдання польської зовнішньої політики у 2019 році. Розділ складається з чотирьох меньших частин, кожній 3 яких передував теоретичний вступ: норми та цінності; важливість історичного чинника у створенні м’якої сили; культура; дипломатія та роль Полонії у побудові іміджу Польщі.

Ключові слова: зовнішня політика; Міністерство закордонних справ Польщі; м'яка сила; дипломатія; культура; історична політика. 